\title{
Fishermen Adaptation to Climate Change in Mertasinga Village, Gunungjati Sub-District, Cirebon Regency
}

\author{
Tjaturahono Budi Sanjoto $^{1 *}$, Hana Anggita Sari ${ }^{2}$, Puji Hardati ${ }^{1}$ \\ ${ }^{1}$ Department of Geography, Universitas Negeri Semarang, Sekaran Campus, Gunungpati, Semarang 50229, Indonesia \\ ${ }^{2}$ Post-Graduate Program, Universitas Negeri Semarang, Sekaran Campus, Gunungpati, Semarang 50229, Indonesia
}

Corresponding Author Email: tjatur@mail.unnes.ac.id

https://doi.org/10.18280/ijsdp.160507

Received: 31 May 2021

Accepted: 1 September 2021

\section{Keywords:}

adaptation, fishermen, climate change

\begin{abstract}
This study aims to determine the adaptation carried out by the fishermen of Mertasinga Village in facing climate change. The population of the study was 2,025 fishermen in Mertasinga Village, and a sample of 102 fishermen was taken using a proportional random sampling technique. Data were collected using observation, interviews, and documentation. Data were analyzed using the interactive analysis model from Miles and Huberman. Based on the results of the analysis, it can be concluded that climate change has an impact on fishing activities that require fishermen to adapt. In fact, they have adapted to climate change even though the used technology is still quite minimal; fishermen have not developed a ship, have not used weather information and maps of fish catchment areas from the BMKG, and have not used fish tracking devices. Carrying out continuous socialization, strengthening social capital and organizational capacity, and holding various trainings concerning on alternative livelihood are greatly essential to do.
\end{abstract}

\section{INTRODUCTION}

Global warming is a fact that is happening for years or even decades. It is a sensational topic at almost all levels of society in the world. The real thing about global warming is climate change. Climate changes continuously due to interactions between its components with external factors such as eruptions, sunlight variations [1], and human activities [1-3]. They thus change the composition of the global atmosphere and natural climate variability over time $[3,4]$.

Climate change is characterized by a tendency to increase in temperature over time, change in rainfall patterns, and increase in sea level [2]. The increase in global temperature since 1901 reached $0.89^{\circ} \mathrm{C}$. In Southeast Asia, the temperature increase reaches $0.4-1^{\circ} \mathrm{C}$. The temperature increase in Southeast Asia in the medium term (2045-2065) is estimated to reach $1.5-2^{\circ} \mathrm{C}$ [4]. Indonesia is one of the most vulnerable countries to the threats and impacts of climate change $[3,5,6]$. The results of data observations for 39 years from 1981-2020 is that the air temperature anomaly in Indonesia in January experienced an increase in the average air temperature of $0.95^{\circ} \mathrm{C}$ [7]. Then, data for 30 years $(1980-2010)$ indicates that there was a change in rainfall, normal annual rainfall [7], and a shift in the peak of rainfall [8].

Indonesia is an archipelago whose $3 / 4$ territory is sea [9]. This causes Indonesia to have a large coastal area as well [10]. Coasts have a very important role in people's lives [11]. However, coastal ecosystems are vulnerable to the impacts of climate change $[12,13]$. Climate change is increasing the vulnerability of coastal areas which are already vulnerable to erosion, destruction of mangrove forests, and exacerbated by human activities such as the construction of docks and sea dikes [14]. Climate change causes changes in coastal and marine ecology [15]. Coasts are vulnerable to sea-level rise, changes in the frequency and intensity of wind speeds, increased wave height, increased ocean temperatures, and increased carbon dioxide concentrations that cause acidification in the oceans [16].

Climate change can disrupt the fish catch of fishermen [17] so that it has an impact on the livelihood systems of coastal communities [18] and the welfare of fishermen resulting in increased uncertainty regarding aspects of fishermen's livelihoods [19]. It also results in the increase and decrease of fisheries in certain areas. This is due to temperature, oxygen availability, and availability of fish food in these waters [13]. If the controlling factor is not suitable in certain waters for fish life, the fish will certainly migrate to waters that have the availability of these controlling factors. Apart from the erratic distribution of fish, rainfall, and wind seasons, climate change also affects capture fisheries. The increasing frequency of big waves is also a challenge for fishermen to reach the fishing ground. Unfavorable water and weather conditions cause fishermen to often delay fishing operational time and affect income from their catch, thus making fishermen and fishermen's families adapt to cope with climate change [13, 20]. Climate change has an influence on changes in the fishing season calendar, the loss of several animals that are markers of changing seasons, and an increase in the intensity of storms in the sea that suddenly come to fishermen in Natuna Regency, Riau Islands [19].

Bajau fishermen, Konawe Regency also feel climate change. Fishermen feel the increased risk of going to sea, reduced fish production, increased costs of fishing, the less effective fishing gear they use, and difficulty determining fishing areas [12]. The impact of climate change felt by fishermen in Indramayu Regency is in the form of high tidal waves, changes in rainfall, 
changes in wind patterns, difficulty reading the weather, and fishing ground that moves further to the high seas [17].

Based on the results of interviews with fishermen in Gunungjati Sub-district, the current weather conditions are difficult to predict, unlike in the past certain months can predict the number of fish. For now, fishermen find it difficult to read natural forecasts. This has an impact on the decreasing fish catch of fishermen, they only look for fish around the coast of Cirebon, for fear of being suddenly hit by high waves.

Data from ref. [21] and ref. [22] also propose that extreme and erratic weather results in much-reduced fish catch, namely from 1 ton per day to 1 quintal per day. If the extreme and erratic weather comes about, then many Merstasinga fishermen do not go sailing [23]. In addition, the production of salted fish is also constrained by the erratic weather [24]. This uncertainty could be influenced by climate change which resulted in disruption of the environmental balance [25]. What is more: climate change causes cycles of climate anomalies such as La Nina and El Nino to become increasingly erratic [26].

Deputy Head of the Meteorology, Climatology, and Geophysics Agency (BMKG) Mulyono R Prabowo explained that one of the causes of waning natural navigation systems cannot be separated from environmental changes, one of which is that global warming is considered to have an effect. News from Tribunnews.com (05/18) states that many fishermen in Cirebon could not go to sea due to bad weather, could only work odd jobs, and some fishermen even sold their belongings to meet their daily needs. Climate variability that occurs in one village in Cirebon Regency has a detrimental impact on fishermen's households. The losses that are felt are decreased fishing yields, decreased production of salted fish, and failure to go to sea [18].

The future climate can be very different from the current. Climate fluctuations potentially will continue [27]. Fishermen are faced with the threat of climate change [28] and must adapt to these conditions for their livelihoods as the uncertain climate has an impact on their economic conditions [29]. Natuna Regency fishermen are pursuing a strategy of diversifying their economic activities, diversifying their fishing gear, changing fishing ground areas, utilizing social networks, and globalizing family members for adaptation to climate change [19]. The use of the development of ship technology, fishing gear, and geo-information and communication technology is carried out to adapt to the impacts of climate change by fishermen in Indramayu Regency [17]. The adaptation strategy taken by Bajau fishermen to deal with climate change is to verify livelihoods, diversify fishing gear, and change the fishing ground area [12].

The richness of the Indonesian sea that is used by fishermen has not provided welfare to fishermen Development needs to be done for the welfare of humans [30]. The fishing profession is greatly vulnerable to the impacts of climate change [13] as it causes sea level rise, changes in sea temperature and acidity, increases in frequency and intensity of extreme weather, and changes in rainfall. Indirectly, climate change influences fishermen's activities and life.

Reflecting on those issues, education still becomes a notable element in finding an exact solution - especially for fishermen. A study [31] mentions that education plays a great role in shaping good attitudes, behavior, and thoughts in the perpetrators regarding the environment. Fishermen play a role in determining the right adaptation strategy to deal with the impacts of climate change. It takes knowledge, attitudes, and appropriate skills to deal with the impacts of climate change so that these impacts can be minimized. It is expected that fishermen are aware and active in determining the right adaptation strategy to minimize the impact of climate change and participate in environmental conservation.

One of the areas possessing greatly potential fishery is Cirebon Regency, West Java Province [32]. There, fishery is one of the various important economic bases for local income [33, 34]. Gunungjati Sub-district is named as a sub-district with the largest fish productivity in Cirebon. Then, of the 15 villages there, Mertasinga Village has the largest fishery products which are even exported abroad [35]. Mertasinga is a fishing village that has existed since the Dutch colonialist still put hands in Indonesia. As a fishing village, it has a very strong fishing culture, adequate fishery infrastructure, and a large fish market and holds fish bazaars regularly [36].

Hence, studies on fishermen, especially the adaptation of fishermen to climate change in Cirebon Regency, are still very minimal. It is necessary to do an in-depth study related to the adaptation of fishermen to climate change in Gunungjati Subdistrict, especially in Mertasinga Village, because most of the people of Mertasinga Village are fishermen who depend on the sea for their livelihoods. The majority of them have already felt the impacts of climate change, such as difficulty reading the seasons, unpredictable weather, high risk of going to sea, and decreasing fish catches. The impact of climate change requires them to adapt. This study aims to determine the adaptation carried out by the fishermen of Mertasinga Village in facing climate change. The results of this study are expected to provide benefits regarding the adaptation of fishermen in facing climate change. They can also be used as a reference for similar research and help the government to create programs that are suitable for fishermen.

\section{METHODOLOGY}

This study applied a mixed research design or better known as mixed methods research. The mixed-methods design in this study used a sequential explanatory type approach. The population in this study was fishermen who live in Mertasinga Village, Gunungjati Sub-district, Cirebon Regency and experience the impact of climate change, namely 2,025 fishermen.

Fishermen in Mertasinga Village are divided into three groups, namely; owner fishermen, small fishermen, and labor fishermen. Owner fishermen are described as fishermen who have their own means or equipment of production such as boats, nets, and others. They are usually upper-class fishermen or skippers who have many production tools. Meanwhile, small fishermen are those with their own production tools but with low quantity and sophistication as they only have little capital. Then, labor fishermen are those who do not have their own means of production. They can only contribute their labor services in fishing activities and earn lower wages than fishermen who own production equipment

Sampling in this study applied a proportional random sampling technique. The proportional random sampling technique was chosen because at the research location, there were three groups or classes of fishermen, namely owner fishermen, small fishermen, and labor fishermen. Each group of fishermen has a different number, so it is necessary to take a proportional sample with the aim that the sample can be taken evenly from each group. The sampling utilized the 
formula from Isaac and Michael to obtain 102 samples. The sample proportion can be seen in Table 1 .

Table 1. Research samples of fishermen in Mertasinga village by class of fisherman 2020

\begin{tabular}{|c|c|c|c|c|}
\hline No & Class & $\begin{array}{c}\text { Total } \\
\text { Population }\end{array}$ & Calculation & $\begin{array}{c}\text { Total } \\
\text { Sample }\end{array}$ \\
\hline 1 & $\begin{array}{c}\text { Owner } \\
\text { Fisherman }\end{array}$ & 623 & $\frac{623}{2025} \times 102$ & 31 \\
\hline 2 & $\begin{array}{c}\text { Small } \\
\text { Fisherman }\end{array}$ & 1.300 & $\frac{1300}{2025} \times 102$ & 66 \\
\hline 3 & $\begin{array}{c}\text { Labor } \\
\text { Fisherman }\end{array}$ & 102 & $\frac{102}{2025} \times 102$ & 5 \\
\hline \multicolumn{2}{|c|}{ Total } & $\mathbf{2 . 0 2 5}$ & & $\mathbf{1 0 2}$ \\
\hline
\end{tabular}

Source: Primary Research Data, 2020

Data collection applied observation, interview, and documentation techniques. In this study, interviews were conducted with research subjects to obtain data about the adaptation of fishermen in facing climate change. The data validity test in this study used triangulation, namely comparing various information obtained from observation, interview, and documentation methods.

The qualitative analysis in this study used the Miles and Huberman model analysis. Steps taken to analyze qualitative data began with reducing the data. Reducing data means summarizing, choosing the main things, focusing on the important things, looking for themes and patterns, and removing unnecessary things. After reduced, the data is presented. In qualitative research, the data presented can be in the form of brief descriptions, tables, graphs, pies, and the like. The presentation makes the data will be easy to understand. Conclusions are drawn after reducing and presenting the data. The conclusion in qualitative research that is expected is a new finding that has never existed before. Findings can be in the form of descriptions of an object. Drawing conclusions in this study is also expected to be able to answer research questions. The research question is how fishermen in Mertasinga Village adapt to and face the climate change.

\section{RESULT AND DISCUSSION}

Cirebon Regency is located in West Java Province. Based on its astronomical location, it is in the position of $6^{\circ} 30^{\prime}$ $7^{\circ} 00^{\prime} \mathrm{S}$ and $108^{\circ} 40^{\prime}-108^{\circ} 48^{\prime} \mathrm{E}$. Mertasinga Village is a village located on the coast of Cirebon Regency and is traversed by the Bondet River which empties into Mertasinga Village. The total population of Mertasinga Village is 6,422 people. 3,262 residents are male and 3,160 are female. They work as PNS, TNI, POLRI, entrepreneurs, employees, laborers, farmers, traders or sellers, and fishermen. $32 \%$ or 2,025 people in Mertasinga Village are fishermen. They are divided into three groups, namely small fishermen, owner fishermen, and labor fishermen. The majority of fishermen in Mertasinga Village are small fishermen and labor fishermen.

This is not supposed to be a part of the paragraph. It is a subpoint of "Results and Discussion" and therefore must be separated and written in bold. You might revise or just simply remove this sentence. In this study, adaptation is a modification process caused by a stimulus. The presence of a stimulus is in the form of an environment that has begun to change due to the impact of climate change. Therefore, fishermen took steps to adjust their livelihoods to this stimulus The adaptation strategy carried out by fishermen in Mertasinga Village can be seen in Table 2 .

The adaptations made by fishermen in Mertasinga Village in facing the impacts of climate change are technological adaptation, social adaptation, and economic adaptation. Technology adaptation is in the forms of ship maintenance, use of GPS, and use of refrigerators. Social adaptation takes forms of joining as a member of a fishing group, following socialization, utilizing social networks, and trading or working family members. Then, economic adaptation is in the form of a double-income pattern and changing professions.

Table 2. Adaptation of fishermen in mertasinga village in facing climate change

\begin{tabular}{|c|c|c|c|}
\hline \multirow{2}{*}{ Class } & \multicolumn{3}{|c|}{ Adaptation } \\
\hline & Technology & Social & Economy \\
\hline $\begin{array}{c}\text { Owner } \\
\text { Fisherman }\end{array}$ & $\begin{array}{l}\text { 1. Ship Maintenance } \\
\text { 2. Using GPS } \\
\text { 3. Using Cold Storage }\end{array}$ & $\begin{array}{l}\text { 1. Joining a fishing group } \\
\text { 2. Buying and selling online with } \\
\text { fishermen outside Cirebon } \\
\text { 3. Following the socialization from } \\
\text { related agencies } \\
\text { 4. Family members work and help with } \\
\text { seafood processing }\end{array}$ & $\begin{array}{l}\text { 1. Cultivation of green fish/shellfish } \\
\text { 2. Opening a side business in the form of a shop } \\
\text { 3. Opening a side business in the form of } \\
\text { services }\end{array}$ \\
\hline $\begin{array}{c}\text { Small } \\
\text { Fisherman }\end{array}$ & $\begin{array}{l}\text { 1. Ship Maintenance } \\
\text { 2. Using Cold Storage }\end{array}$ & $\begin{array}{l}\text { 1. Join a fishing group } \\
\text { 2. Utilizing social networks with } \\
\text { bosses/middlemen } \\
\text { 3. Following the socialization from } \\
\text { related agencies } \\
\text { 4. Family members work and help with } \\
\text { seafood processing }\end{array}$ & $\begin{array}{l}\text { 1. Switching professions to become } \\
\text { farmers/breeders } \\
\text { 2. Switching professions to become farm } \\
\text { laborers/ponds } \\
\text { 3. Switching professions to become } \\
\text { construction workers/porters } \\
\text { 4. Cultivating green mussels in groups with } \\
\text { other fishermen } \\
\text { 5. Opening a side business in the form of a } \\
\text { shop/service }\end{array}$ \\
\hline $\begin{array}{c}\text { Labor } \\
\text { Fisherman }\end{array}$ & $\begin{array}{l}\text { Helping the maintenance } \\
\text { of the ship }\end{array}$ & $\begin{array}{l}\text { 1. Joining a fishing group } \\
\text { 2. Utilizing social networks with } \\
\text { bosses/middlemen } \\
\text { 3. Family members work and help with } \\
\text { seafood processing }\end{array}$ & $\begin{array}{l}\text { 1. Switching professions to become farm } \\
\text { laborers/ponds } \\
\text { 2. Switching professions to become } \\
\text { construction workers/porters } \\
\text { 3. Opening a side business in the form of a shop }\end{array}$ \\
\hline
\end{tabular}

Source: Primary Research Data, 2020 
The knowledge of fishermen about weather and climate and their implications for the management strategy of marine and fisheries resources has changed over time. The uncertainty of fishing seasons and reduced catches make them try to develop technology and adapt to changing conditions. The use of ship technology and fish storage is executed to adapt to the impacts of climate change by fishermen. The use of technology is very beneficial to prevent or reduce the impact and/or risk that may occur so that it will reduce the costs required. This is under the results of interviews conducted by researchers to one of the fishermen named Seta:

"In Mertasinga, most people are fishermen. If the boat is damaged, just fix it. If the engine is damaged, the business repairs it first. If it can't work at all, then replace it."

From the results of interviews with fishermen in Mertasinga Village, the technology used in fishing boats is in the form of 15-40 PK outboard motors and if the boat's body is damaged, the fishermen repair the boat themselves. The technology used by fishermen is still simple as the majority of fishermen in Mertasinga Village are small fishermen using outboard motorboats. Small fishermen have not used GPS for determining the catchment area, but fishermen who own boats of 5-10 GT have already used GPS - as explained by $\mathrm{Mr}$. Juned below:

"My ship is 10 GT using GPS. The big ships use GPS for sailing."

In addition to the use of GPS, fishermen in Mertasinga also utilized cold storage or refrigerators at Bondet Fishing Port to extend the life of the fish. Another adaptation is in the form of fish preservation for the manufacture of salted fish by traditional drying in the sun. The process of making salted fish is usually done by fishermen's wives and children when fishermen go out to sea.

The use of social networks is an adaptation carried out by fishermen in Mertasinga Village by optimizing family members. Social networks consist of two relationships, namely vertical social relationships and horizontal social relationships. Vertical social relationship talks about the relationship between skippers (owners) and fishermen; the skippers provide capital to go to sea. Meanwhile, horizontal social relationship is in the form of cooperation between fishermen and fishermen and fishermen with coastal communities who have livelihoods on land. When small fishermen face difficulties to find fish, they seek capital by utilizing their social network to the skippers. Fishermen are looking for capital to go to sea or are forced to go into debt to meet their daily needs and will pay them during the high season. The influence of climate change on social conditions in Mertasinga Village also adds to the social network among fishermen outside the region. This is proved by an interview with Mr. Didi:

"...when famine comes, the owner fishermen exchange any relationships online, sell frozen fish-usually taken from Surabaya and Banten..."

From the results of interviews conducted by researchers, it is known that the fishermen of Mertasinga Village face difficulties to find fish in the dry season. The owner fishermen then communicate online with other fishermen who are outside the Cirebon area. If the fish stocks in Cirebon Regency run out because the fishermen do not get fish, the owner fishermen take the fish stocks from other areas. Fishermen buy and sell fish in frozen form. The fishermen relations of Mertasinga Village have reached other regions such as East Java, Central Java, and the coastal parts of Banten. Fishermen with many family members tend to have extensive social networks or relationships. Another social adaptation is in the form of an annual nadran ceremony. This local wisdom is a hereditary legacy that is held annually. Nadran takes place at the end of the western season in April. It is a symbol of gratitude for the abundant marine products and the hope for abundant seafood in the following year.

The economic adaptation carried out by fishermen to deal with climate change is by means of a double income pattern or changing professions temporarily and leaving fishing activities or changing professions. The double income pattern of fishermen is in the form of changing professions temporarily when it is difficult to fish, usually during the beetle season and the western season. When it is difficult to get fish, fishermen turn to porters, construction workers, farming, raising livestock, opening shops in the surrounding area, opening side service businesses, working as farm laborers, and working as fishpond laborers. This is in line with the interview with Mr. Saduri as follows:

"When it's the hard season, I usually work as a coolie or laborer at the Celangcang market or when someone builds a house. Sometimes I rent my boat, and being a farmer is also just fine. Just do everything."

The majority of fishermen in Mertasinga Village do odd jobs as coolies or casual laborers when they are difficult to get fish. The following is an interview with Mr Sarkad who owns lands for farming:

"Apart from fishing, my side job is planting bananas on my land. So if hard season comes, I can sell the fish or eat the bananas right away."

Fishermen have also adapted to raising chickens and goats that can be used for their own consumption or for sale in markets. Fishermen who own lands for farming or livestock also do these jobs as both can increase their income and have unlimited time. Simply, they can do it all year round. Apart from farming and raising livestock, fishermen also adapt to selling or trading in their yards. The shop is managed by the fishermen's wife, selling various shellfish and fresh fish, snacks for children, and basic necessities such as soap, detergent, rice, sugar, and others. Another fishermen's economic adaptation is changing professions and leaving fishing activities at sea. This change of profession is like raising green clams and working as a farm laborer.

\section{CONCLUSION}

Based on the results of research on the adaptation of fishermen to climate change in Mertasinga Village, Gunungjati Sub-district, Cirebon Regency, it can be concluded that fishermen have experienced climate change that has an impact on their lives so that fishermen have to adapt to the situation. The adaptations carried out by fishermen in Mertasinga Village include 1) technology adaptation, namely in the form of utilizing GPS technology and refrigerators; 2) social adaptation, carried out by communication between fishermen and fishermen and middlemen; 3) economic adaptation, carried out by fishermen, namely with a double income pattern and leaving fishing activities.

\section{RECOMMENDATION}

The technology for adapting that is used by fishermen in 
Mertasinga Village is still very minimal such as fish processing technology by drying the fish directly in the sun. It can be said that this method is still traditional because it depends on the weather. The local government should be able to provide drying tools for drying fish that can be used by fishermen and can optimize fishermen's work. Fishermen in Mertasinga Village are still minimally used, such as GPS, technology. Only owner fishermen owning the new 5-10 GT boat use GPS. Fishermen also do not know the fish catch area distribution map that has been provided by the relevant agencies. The local government should work even harder by holding outreach for fishermen in Mertasinga Village, especially regarding the use of GPS, the use of maps of fish catchment areas, and the use of fish detection tools. The fishermen who are given the socialization must also be from all classes. Various socializations have to be held regularly and continuously - not only incidentally - so that fishermen can obtain adequate information and skills to deal with important matters in terms of fishery dynamics. Apart from the local government, fishermen must also be willing to work together to succeed in socialization programs by regularly attending socialization activities and having the intention of adding knowledge which will certainly be beneficial for life.

Moreover, escalating social capital between fishermen and the government is very notable for cooperation in dealing with climate change. Strengthening solidarity and the capacity of fishermen's organizations is greatly prominent so that fishermen can exist continuously even in the midst of a fluctuating climate. The government must provide alternative livelihood training for the community and empower women so that fishermen do not only rely on their income from the fisheries sector. Soft skills such as entrepreneurship and other creative industries are extremely recommended.

\section{ACKNOWLEDGMENT}

We would like to thank to Direktorat Riset dan Pengabdian Kepada Masyarakat (DRPM) Indonesia to grant the research program. We would also like to thank the Post-graduate Program and LPPM UNNES for approving the research proposal.

\section{REFERENCES}

[1] KLHK. (2017). Mengenai Perubahan Iklim. Direktorat Jenderal Pengendalian Perubahan Iklim. http://ditjenppi.menlhk.go.id/kcpi/index.php/infoiklim/perubahan-iklim.

[2] Adibroto, T.A., Purwanta, W., Oktivia, R., Erowati, D.A., Suryanto, F., Sudaryono, Nugrogo, R., Hartaya, Rini, S.D. (2011). IPTEK Untuk Adaptasi Perubahan Iklim: Kajian Kebutuhan Tema Riset Prioritas. Dewan Riset Nasional.

[3] Miranti, R., Widhiyoga, G., Haqqi, H. (2018). Analisis pembangunan berkelanjutan terhadap kebijakan perubahan iklim Indonesia sebagai upaya mengakomodasi Paris Agreement. Transformasi, I(34): 56-68.

[4] Intergovermental Panel of Climate Change. (2015). Climate Change 2014Synthesis Report. World Meteorological Ogranization.

[5] KLHK. (2018). Arah Kebijakan dan Sasaran Adaptasi
Perubahan Iklim di Indonesia. Kementrian Lingkungan Hidup Kehutanan.

[6] Qodriyatun, S.N. (2016). Upaya mitigasi dan adaptasi perubahan iklim. Info Singkat Kesejahteraan Sosial, VIII(01): 9-12.

[7] BMKG. (2020a). Ekstrem Perubahan Iklim. Badan Meteorologi, Klimatologi, Dan Geofisika. https://www.bmkg.go.id/iklim/?p=ekstrem-perubahaniklim.

[8] Rochmayanto, Y., Sakuntaladewi, N., Wibowo, L.R., Kehutanan, K. (2014). Pengarus-utamaan Biaya Adaptasi terhadap Perubahan Iklim dalam Perencanaan Pembangunan. Policy Brief, 8(5): 1-8.

[9] Lailiyah, A., Juhadi, Tjahjono, H. (2018). Strategi Coping Nelayan Terhadap Perubahan Iklim Studi, Pada Masyarakat Nelayan di Kecamatan Tugu, Kota Semarang Jawa Tengah. Geo Image (Spatial-EcologicalRegional), 7(1): 47-53. https://doi.org/10.15294/geoimage.v7i1.23396

[10] Rahayu, S., Jayusman, Romadi. (2017). Dinamika kehidupan sosial ekonomi nelayan desa sirnoboyo kabupaten pacitan tahun 1998-2014. Journal of Indonesian History, 6(1): 55-65.

[11] Sanjoto, T.B., Hardati, P. (2010). Kajian Kualitas Perairan Pesisir Kabupaten Kendal Menggunakan Teknologi Penginderaan Jauh Multi Sensor.

[12] Dewiyanti, S., Maruf, A., Indriyani, L. (2019). Adaptasi nelayan bajau terhadap dampak perubahan iklim di pesisir soropia kabupaten konawe, sulawesi tenggara. Ecogreen, 5(1): 23-29. http://ojs.uho.ac.id/index.php/green/article/view/4796

[13] Intergovermental Panel of Climate Change. (2014). Climate Change 2014: Impacts, Adaptation, and Vulnerability. Part A: Global and Sectoral Aspects. Cambridge University Press. www.cambridge.org.

[14] Subair, Kolopaking, L.M., Adiwibowo, S., Pranowo, B.M. (2014). Adaptasi perubahan iklim komunitas Desa: Studi kasus di kawasan pesisir utara pulau ambon. Komunitas, $6(1)$ : $57-69$. https://doi.org/10.15294/komunitas.v6i1.2943

[15] Patriana, R., Satria, A. (2013). Pola adaptasi nelayan terhadap perubahan iklim: studi kasus nelayan dusun ciawitali, desa pamotan, kecamatan kalipucang, kabupaten ciamis, Jawa Barat. Jurnal Sosial Ekonomi Kelautan Dan Perikanan, 8(1): 11-23. https://doi.org/10.15578/jsekp.v8i1.1191

[16] Zikra, M., Suntoyo, Lukijanto. (2015). Climate Change Impacts on Indonesian Coastal Areas. Procedia Earth and Planetary Science, 14: 57-63. https://doi.org/10.1016/j.proeps.2015.07.085

[17] Sagala, S.A., Argo, T.A., Asirin, Adhitama, P., Dodon. (2016). Strategi adaptasi nelayan terhadap dampak perubahan lingkungan (Studi Kasus: Pemanfaatan Teknologi Penangkapan Ikan Laut). Penataan Ruang, 11(2): $22-35$ https://dx.doi.org/10.12962/j2716179X.v11i2.5216

[18] Perkasaputra, A. (2018). Mekanisme Adaptasi Nelayan Dalam Menghadapi Variabilitas Iklim (Studi Kasus: Desa Samadikun, Kecamatan Kejaksan, Kota Cirebon, Provinsi Jawa Barat). Institut Pertanian Bogor.

[19] Wibowo, A., Satria, A. (2016). Strategi Adaptasi Nelayan di Pulau-Pulau Kecil terhadap Dampak Perubahan Iklim (Kasus: Desa Pulau Panjang, Kecamatan Subi, Kabupaten Natuna, Kepulauan Riau). 
Sodality: Jurnal Sosiologi Pedesaan, 3(2). https://doi.org/10.22500/sodality.v3i2.11336

[20] Samah, A.A., Shaffril, H.A.M., Hamzah, A., Samah, B.A. (2019). Factors affecting small-scale fishermen's adaptation toward the impacts of climate change: Reflections From Malaysian Fishers. Sage, 1(11): 1-11. https://doi.org/10.1177/2158244019864204

[21] Radar Cirebon. (2021). Nelayan Tak Melaut Akibat Cuaca Ekstrem. https://www.radarcirebon.tv/2021/01 /05/nelayan-tak-melaut-akibat-cuaca-ekstrem/.

[22] Radar Cirebon. (2019). 4 Bulan Hasil Tangkap Ikan Berkurang. https://www.radarcirebon.tv/2019/10/31/4bulan-hasil-tangkap-ikan-berkurang/.

[23] Kisdiantoro. (2014). Cuaca Ekstrem, Nelayan Desa Mertasinga Memilih Tak Melaut. https://jabar.tribunnews.com/2014/01/17/cuacaekstrem-nelayan-desa-mertasinga-memilih-tak-melaut.

[24] Kumparan. (2018). Karena Faktor Cuaca, Harga Ikan Asin di Kabupaten Cirebon Naik. https://kumparan.com/about-cirebon/karena-faktorcuaca-harga-ikan-asin-di-kabupaten-cirebon-naik/full.

[25] Hariandja, R. (2020). BMKG: Perubahan Iklim Picu Cuaca

Ekstrem. https://www.mongabay.co.id/2020/01/06/bmkgperubahan-iklim-picu-cuaca-ekstrem/.

[26] Radar Cirebon. (2019). La Nina Penyebab Cuaca Tak Menentu, Maret Masih Ada Potensi Hujan Lebat. https://www.radarcirebon.com/2019/03/02/la-ninapenyebab-cuaca-tak-menentu-maret-masih-ada-potensihujan-lebat/.

[27] Trewartha, G.T. (1995). Pengantar Iklim (5th ed.). Gajah Mada University Press.

[28] Akbar, T., Huda, M. (2017). Nelayan, Lingkungan, dan Perubahan Iklim (Studi Terhadap Kondisi Sosial Ekonomi Pesisir di Kabupaten Malang). Wahana, 68(1):
27-38. https://doi.org/10.36456/wahana.v68i1.630

[29] Sinaga, H. (2019). Strategi Pemberdayaan Masyarakat Nelayan Untuk Meningkatkan Kesejahteraannya Di Kelurahan Sibolga Ilir Kecamatan Sibolga Utara Kota Sibolga. Tapian Nauli, 1(1): 1-13.

[30] Hardati, P. (2018). Spatial distribution of livelihood assets of tourism village in west ungaran subdistrict semarang regency central Java Province Indonesia. Advances in Social Sciences, Education and Humanities Research (ASSEHR), 313: 279-284. https://doi.org/10.2991/icorsia-18.2019.68

[31] Nugroho, M., Hariyanto, Suharini, E. (2017). Perilaku Peduli Lingkungan Siswa Sekolah Adiwiyata Perdesaan dan Perkotaan Di Jawa Tengah Tahun 2016. Edu Geography, 1(26-34).

[32] Dirja, Faturrohman, M.I. (2019). analisis faktor produksi tangkapan ikan dengan jaring rampus di pelabuhan perikanan pantai (PPP) bondet kabupaten cirebon, Jawa Barat. Barakuda 45, 1(2): 46-56. https://doi.org/10.47685/barakuda45.v1i2.41

[33] Gumilang, A.P. (2019). Analisis daya saing sektor perikanan di kabupaten cirebon. Barakuda 45, 1(1): 1-7. https://doi.org/10.47685/barakuda45.v1i1.14

[34] Putri, D.A. Ilpah, I. (2019). Efektifitas komposisi hasil tangkap bubu lipat (fish trap) di pangkalan pendaratan ikan (PPI) gebang mekar kabupaten cirebon. Barakuda 45, 1(1): 8-17. https://doi.org/10.47685/barakuda45.v1i1.15

[35] Djuwita, D. (2015). Peran perempuan masyarakat pesisir dalam meningkatkan pendapatan keluarga nelayan di desa mertasinga. Al-Amwal, 7(2): 144-155. https://dx.doi.org/10.24235/amwal.v7i2.203

[36] Fabiani, R.R. (2018). Riverfront Fish Market di Kampung Nelayan Mertasinga, Cirebon. Universitas Islam Indonesia. 